\title{
STUDIES OF TRAMEX SOLVENT
}

I. EFFECTS OF MAJOR IMPURITIES

IN TERTIARY AMINE EXTRACTANTS

E. G. Orebaugh

SRL

RECORD COPY

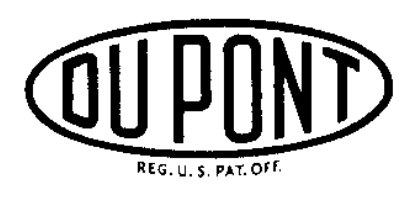

Savannah River Laboratory

Aiken, South Carolina 


\section{LEGAL NOTICE}

This report was prepared as an account of Government sponsored work. Neither the United States, nor the Commission, nor any person acting on behalf of the Commission:

A. Makes any warranty or representation, expressed or implied, with respect to the accuracy, completeness, or usefulness of the information contained in this report, or that the use of any information, apparatus, method, or process disclosed in this report may not infringe privately owned rights; or

B. Assumes any liabilities with respect to the use of, or for damages resulting from the use of any information, apparatus, method, or process disclosed in this report.

As used in the above, "person acting on behalf of the Commission" includes any employee or contractor of the Commission, or employee of such contractor, to the extent that such employee or contractor of the Commission, or employee of such contractor prepares, disseminates, or provides access to, any information pursuant to his employment or contract with the Commission, or his employment with such contractor.

Printed in USA. Price $\$ 1.00$

Avallable from the Clearinghouse for Federal sclentific and Technical Information, National Bureau of Standards,

U. S. Department of Commerce, Springfleld, Virginia 


\title{
STUDIES OF TRAMEX SOLVENT \\ I. EFFECTS OF MAJOR IMPURITIES \\ IN TERTIARY AMINE EXTRACTANTS
}

\author{
by \\ Errol G. Orebaugh
}

Approved by

H. M. Kelley, Research Manager Analytical Chemistry Division

February 1965

\author{
E. I. DU PONT DE NEMOURS \& COMPANY \\ SAVANNAH RIVER LABORATORY \\ AIKEN, SOUTH CAROLINA \\ CONTRACT AT(07.2)-1 WITH THE \\ UNITED STATES ATOMIC ENERGY COMMISSION
}




\section{ABSTRACT}

Secondary amines were found to be the major impurities in commercial lots of three tertlary amines: "Alamine" 336, "Alamine" 336-S, and "Adogen" 364. These impurities form precipitates or emulsions when the tertiary amines are used as the extractant for americium and curium in the Tramex process. Tentative purchase specifications for Tramex extractant are proposed. 


\section{CONTENTS}

Page

Introduction ................... 5

Summary ..................... 5

D1scussion ................. 6

Commerclal Tert1ary Amlne Extractants . . . . . . 6

Primary and Secondary Amine Impurities . . . . . 7

Other Impurities . . . . . . . . . . . 8

Precipitate Formation on Amine Contact with $\mathrm{LICl}-\mathrm{HCl} .8$

Specifications . . . . . . . . . . . . 10

Bibllography . . . . . . . . . . . . . . 12

List of Tables

Table

I Manufacturers' Specifications for Tertiary Amine Extractants . . . . . . . . . . 6

II Observations and Comparisons of Extractants . . 9 


\title{
STUDIES OF TRAMEX SOLVENT \\ I. EFFECTS OF MAJOR IMPURITIES \\ IN TERTIARY AMINE EXTRACTANTS
}

\author{
INTRODUCTION
}

A tertiary amine extractant is used in the Tramex process for the separation of americium and curlum from lanthanides and fission products. (1) In laboratory-scale demonstrations of the process with non radioactive synthet1c feeds, problems arose when highly stable emulsions were formed or when voluminous precipitates appeared in the solvent phase. This adverse behavior was attributed to impurities in the extractant, and a program was initiated to identify and characterize the behavior of these impurities.

This report describes the determination of the major impurities in commerclal lots of "Alamine" 336, * "Alamine" 336-s, and "Adogen" 364** and recommends specifications for the purchase of amine extractants for use in the process.

\section{SUMMARY}

Secondary amines were the principal impurities in commercial lots of "Alamine" 336, "Alamine" 336-S, and "Adogen" 364. Conditions were defined under which these impurities tended to precipitate or form emulsions. Other impurities were shown to be present but were not Identified.

Tentative specifications for the purchase of Tramex extractants were established.

\footnotetext{
* "Alamine" is a trademark of General Mills.

* "Adogen" is a trademark of Archer Daniels M1dland Company for fatty nitrogen compounds.
} 


\section{DISCUSSION}

\section{COMMERCIAL TERTIARY AMINE EXTRACTANTS}

Three commercially avallable tertlary amines, "Alamine" 336 (technical grade), "Alamine" 336-S (reagent grade), and "Adogen" 364, were invest1gated during May 1963-February 1964. The manufacturers' specifications for these products are ilsted in Table I. Since the time of this work, both manufacturers of the amines have expressed willingness to supply fatty tertiary amines of exceptionally high purity.

\section{TABLE I}

Manufacturers' Specifications for Tertiary Amine Extractants

\begin{tabular}{|c|c|c|c|}
\hline & "Alamine" 336 & "Alemine" 336-S & "Adogen" 364 \\
\hline Alkyl-ehain length distribution & $\begin{array}{l}\mathrm{C}_{8}-\mathrm{C}_{10} \text { mixture } \\
\text { w1th the } \mathrm{q}_{8} \\
\text { predominating }\end{array}$ & $\begin{array}{l}\mathrm{C}_{8}-\mathrm{C}_{20} \text { mixture } \\
\text { with the } \mathrm{C}_{8} \\
\text { predominating }\end{array}$ & $\begin{aligned} 5 \% & c_{6} \\
60 \% & c_{8} \\
33 \% & c_{10} \\
2 \% & c_{12}\end{aligned}$ \\
\hline Amlne value $(a)$ & 134 & (b) & 141 \\
\hline \multicolumn{4}{|l|}{ Tert1ary-amine content, $\not$} \\
\hline $\begin{array}{l}\text { Minimum } \\
\text { TypicaI }\end{array}$ & $\begin{array}{l}90 \\
95\end{array}$ & 99 & $\begin{array}{l}95 \\
97\end{array}$ \\
\hline \multicolumn{4}{|l|}{ Secondary-amine content, $\phi$} \\
\hline $\begin{array}{l}\text { Maximum } \\
\text { Typ1cal }\end{array}$ & $\begin{array}{l}4 \\
1.5\end{array}$ & (b) & $\begin{array}{l}4 \\
1.4\end{array}$ \\
\hline \multicolumn{4}{|l|}{ Primary-amtne content, $\%$} \\
\hline $\begin{array}{l}\text { Max1mum } \\
\text { Typ1cal }\end{array}$ & $\begin{array}{l}2 \\
-\end{array}$ & (b) & $\begin{array}{l}2 \\
-\end{array}$ \\
\hline \multicolumn{4}{|l|}{ Water content, $\phi$} \\
\hline $\begin{array}{l}\text { Moximum } \\
\text { Typtcal }\end{array}$ & $\begin{array}{l}0.5 \\
0\end{array}$ & (b) & $\begin{array}{l}0.5 \\
0.1\end{array}$ \\
\hline
\end{tabular}

(a) KOH equivalent: mg $\mathrm{KOH}$ per g amine.

(b) Not stated, but should be at least as good as "Alamine" 336

Early analytical work was concerned with the identification of deleterious impurities in "Alamine" 336 and "Alamine" 336-S. However, after available commercial lots of "Adogen" 364 performed more efficlently under Tramex process conditions than avallable commercial lots of "Alamine" 336 and "Alamine" 336-S, subsequent analytical work was centered on "Adogen" 364 . Consequently, evaluation of "Alamine" 336 was discont1nued before definitive data were obtained, and certain phases of the work on "Alamine" 336-s were not completed. 


\section{PRIMARY AND SECONDARY AMINE IMPURITIES}

The most probable impurity in a tertiary amine is secondary amine. of several known methods for the determination of secondary (and/or primary) amines, the near-infrared spectrophotometric method of Lohman and Norteman $(2)$ was chosen. Though the limit of detection is relatively high ( 0.3 wt $\%$ as dioctylamine), the method was adopted because of its simplicity and speed. Reference standards of tertiary amines were obtained by acetylating "Adogen" 364 with acetic anhydride to convert do not contribute to the analytical absorption band. "Adogen" 364 and "Alamine" 336-S each contalned about 2 wt \% secondary amine (as dioctylamine). "Alamine" 336-S contained only 1.0 wt \% secondary amine after being passed through a charcoal column. No primary amines were detected, but the detection limt for primary amines was 0.2 wt \% (as octylamine).

Poor phase separation resulted when diethylbenzene (DEB) solutions of primary and secondary octylamines were contacted with solutions of $11 \mathrm{M}$ IICI-0.02N HCl. When 1 wt $\%$ dioctylamine 1 D DEB was contacted with the LiCl solution, phase separation was quite slow and some solids were produced in the organic phase and settled at the interface. In contrast to the behavior of dioctylamine, mono-octylamine at concentrations of $\sim 0.7$ wt $\%$ in DEB produced some foaming, and although disengagement was fairly rapid, the aqueous phase remained turbid. At higher concentrations of mono-octylamine, the aqueous phase formed a solid gel.

Passage of free "Alamine" 336 through a coconut-charcoal filter removed the pale yellow coloration from the amine and produced an extractant that performed satisfactorliy in subsequent mixer-settler process studies. This charcoal-treated material produced no precipitate upon contact with IIM IICI-0.02N HCl elther as the free amine or as the amine hydrochloride. Analysis of a chloroform eluate from the charcoal indicated that the charcoal column had reduced the concentration of secondary amine. The yellow component was eluted also, but it was not separated from the residual tertiary amine with which it was co-sorbed on the charcoal.

The samples of "Alamine" 336-S and "Adogen" 364 that were contacted with IIM LICI-0.02N HCl gave almost equal amounts of precipitate, but in subsequent process development tests in the mixer-settlers, "Adogen" 364 performed better than "Alamine" 336-S. "Alamine" 336 gave significantly greater amounts of precipitate and performed poorly in the process tests. Samples that were flist charcoal treated produced little or no precipitate and performed adequately in process tests.

Repeated contact with IIM LICI-0.02N HCl depleted the deleterious species from each of the extractants that were tested. Depletion of 
the precipitate-forming species did not remove the yellow coloration from the extractant. From this it was concluded that the coloration was not deleterious to the process.

\section{OTHER IMPURITIES}

"Alamine" 336 and "Alamine" 336-S contained a reducible specles detectable by polarographic methods at +1.8 volts vs. a standard calomel electrode. Charcoal treatment removed the species. "Adogen" 364 did not contain such a species. The reduction wave did not result from amine oxides or lower amines, but this specles was not 1dentified further.

Impurities that might be deleterious could arise from the production process for the tertiary amine. Such impurities were not detected in "Alamine" 336, "Alamine" 336-S, and "Adogen" 364, but were detected in "Adogen" 363, a tertiary amine differing from "Adogen" 364 only in that its alkyl-chain distribution is $\mathrm{C}_{12}$-centered instead of $\mathrm{C}_{8}$-centered (Table I above). "Adogen" 363 precipitated sollds when maintained at $20^{\circ} \mathrm{C}$. When these solids were washed with cold hexane, a white powder remained. The X-ray diffraction pattern of the powder approximated that of typical glycerides. Hydrolysis of the powder with sodlum hydroxide ylelded a solid, whose infrared spectrum was typical of a long-chain carboxylic acid salt. Acldification of this salt produced a solld, whose Infrared spectrum was that of a carboxylic ac1d. It was concluded that certain fatty-acid starting materials were carried through the process unreacted or that crosscontamination had occurred during manufacture or packaging.

One lot of "Adogen" 364 contained a volumlnous solld, which was removed by centrifugation before the extractant was used in the process. The removed solid was flltered free of excess tertiary amine and washed with cold hexane. X-ray diffraction data indicated a crystal structure similar to that of refined paraffin wax. The melting point was $70^{\circ} \mathrm{C}$. The gray coloration of the material indicated a possible mixture. The major fraction ( $80 \%$ ) of the solid was soluble in chloroform, and the insoluble residue was olive brown and apparently inorganic. Evaporation of the chloroform produced a white solid. Ne1ther solid was identifled.

\section{PRECIPITATE FORMATION ON AMINE CONTACT WITH LICI-HCL}

All precipitates were obtained by contacting the free amines in hexane with IIM $\mathrm{LICl}-0.02 \mathrm{~N} \mathrm{HCl,} \mathrm{since} \mathrm{considerably} \mathrm{larger} \mathrm{quantities}$ of precipitate were formed when tests were made with free amines instead of amine hydrochlorides, and with hexane diluent instead of DEB. The 
precipitates were washed with hexane and water without appreciable losses. Data on the precipitates formed from varlous extractants are summarized in Table II.

TABIE II

Observations and Comparisons of Extractants

\begin{tabular}{|c|c|c|c|}
\hline & \multicolumn{2}{|c|}{ "Alamine" 336-S } & "Adogen" 364 \\
\hline & Untreated & Charcoal-Treated & Untreated \\
\hline L1C1 prec1p1tate ${ }^{(a)}$ & copious & none & moderate \\
\hline LICI. precipitate ${ }^{(b)}$ & moderate & none & very light \\
\hline LICl preclpitate $(\mathrm{c})$ & very light & none & none \\
\hline Secondary amine, $\%(d)$ & $\sim 2$ & $\sim 1$ & $\sim 2$ \\
\hline Reducible species & $\begin{array}{l}\text { polarographic } \\
\text { wave at }-1.8 \mathrm{v} \\
\text { vs. S.C.E. }\end{array}$ & no wave & no wave \\
\hline
\end{tabular}

(a) Formed when free amine undiluted or with hexane diluent was contacted with I.IM LICI-0.02N HCl.

(b) Formed when $0.6 \mathrm{M}$ free amine in $\mathrm{DEB}$ was contacted with $11 \mathrm{M}$ LiCl-0.02N $\mathrm{HCl}$.

(c) Formed when $0.6 \mathrm{M}$ amine hydrochloride in $\mathrm{DEB}$ was contacted w1th $11 \mathrm{M}$ $\mathrm{LICl}-0.02 \mathrm{~N} \mathrm{HCl}$.

(d) By near-infrared spectrophotometric method of Lohman and Norteman. (2)

The precipltate from "Adogen" 364 was mainly dioctylamine hydrochloride, but the precipitate from "Alamine" 336-s was 1dentified as a mixture of secondary amine hydrochlorides with an alkyl-chain distribution different from that of "Adogen" 364. Dilute hydrochloric ac1d was solely responsible for the preclpitation. The "Adogen" 364 precipitate was similar to dioctylamine hydrochloride with respect to color (pink), melting point $\left(205-220^{\circ} \mathrm{C}\right)$, crystal structure (X-ray diffraction), infrared spectra, and reactivity with various reagents such as concentrated $\mathrm{H}_{2} \mathrm{SO}_{4}$. The "Alamine" 336-S precipitate compared slmilarly except that its color was off-white and it was more gelatinous.

A preclpitate that formed when IIM LICI-0.02N HCI contacted a process solution of $30 \mathrm{vol} \%$ "Alamine" 336 hydrochloride in DEB was not identifled. However, it is unlikely that this precipitate was entirely secondary amine hydrochloride in view of the solubility of dloctylamine hydrochloride in solutions of tertiary amine hydrochlorides in DEB. 
Before the precipitates were identified, they were thought to be carbamates, because upon exposure to air primary and secondary amines were observed to form solids that were ldentifled as ammonium carbamates. Such carbamate salts evolve carbon dioxide when treated with sulfuric ac1d. However, when gas evolved from the precipitates was analyzed by mass spectrometry, carbon dioxide was found to be a minor constituent in comparison with hydrogen chloride. Though the presence of significant quantities of carbamate may be rejected, small quantities may be present, and if the primary-amine contents of the extractants are not kept quite low, trouble from carbamate formation might arise.

\section{SPECIFICATIONS}

There are a number of potential impurities in tertiary amine extractants that could cause emulsification or precipitation problems in the Tramex process if present in sufficient quantities. Secondary amines are quite troublesome because their acld salts can preclpitate when the extractant is contacted with acidic lithium chloride solutions. The solubility of the acld salts in DEB apparently varies with the alkyl-chain length of the secondary amine impurity. Although "Adogen" 364 with 2 wt $\%$ secondary amine has performed adequately in the process, a secondary amine specification of 1 wt $\%$ maximum would be desirable in view of the fact that alkyl-chain length distributions might vary. Primary amines, although not likely to be present to any great extent in the extractants, cause poor phase disengagement. No detectable amounts ( 0.2 wt \% by near-infrared method) should be present. Other impurities, e.g. the reducible species present in "Alamine" 336-S, in the starting materials and in the manufacturing intermediates must be excluded.

It is impossible to predict all impurities that could be present in tertiary amine extractants, and some variations in purity have been observed from lot to lot of the same extractant. To provide guidelines for the purchase of a satisfactory extractant from any commercial source, the following tentative specifications are recommended:

1. Tertiary amine content: 99 wt $\%$ or greater

2. Secondary amine content: 1 wt $\%$ or less

3. Primary amine content: 0.2 wt $\%$ or less

4. Particulate solids: absent 
5. Alkyl-chain length distribution: greater than $90 \%$ in $\mathrm{C}_{8}-\mathrm{C}_{10}$ range; no components with cha1n lengths greater than $\mathrm{C}_{12}$, nor less than $\mathrm{C}_{6}$.

6. Starting materials or production intermediates, e.g., glycerides, amines, and alcohols: absent

7. Polarographically reducible species (especially those giving a wave at -1.8 volts vs. S.C.E.): absent

8. Use test (must pass satisfactorily):

a. Make a solution of 30 vol $\%$ extractant in diethylbenzene.

b. Neutralize extractant by contacting solvent with an equal volume of $1 \mathrm{M} \mathrm{HCl}$.

c. Remove aqueous phase and contact neutralized solvent with an equal volume of $0.01 \mathrm{M} \mathrm{KCl}$. The contact with $0.01 \mathrm{M} \mathrm{HCl}$ will remove excess hydrogen chloride from the solvent.

d. Remove aqueous phase and contact organic phase with an equal volume of IIM IiCl-O.02M $\mathrm{HCl}$.

No precipitates should form and the phases should disengage cleanly within 5 minutes. Disengaging time is highly dependent upon the hydrochloric acid concentration in the aqueous lithium chloride solution. 


\section{BIBLIOGRAPHY}

1. R. D. Baybarz, B. S. Weaver, and H. B. Kinser. "Isolation of Transplutonium Elements by Tertiary Amine Extraction." Nucl. Sc1. Engr. 17, 457-62 (1963).

2. F. H. Lohman and W. E. Norteman, Jr. "Determination of Primary and Secondary Allphat1c Amines by Near-Infrared Spectrophotometry." Anal. Chem. 35, 707-11 (1963). 